\title{
Correction to: COVID-19 pandemic: the 3R's (reduce, refine, and replace) of personal protective equipment (PPE) sustainability
}

Vivian Ip, MBChB, FRCA · Timur J. P. Özelsel, MD, DESA •

Rakesh V. Sondekoppam, MBBS, MD - Ban C. H. Tsui, MD, MSc, FRCPC

Published online: 22 April 2020

(C) Canadian Anesthesiologists' Society 2020

\section{Correction to:}

\section{Canadian Journal of Anesthesia/Journal canadien} d'anesthésie

https://doi.org/10.1007/s12630-020-01653-0

This article was updated to fix a typo in the title introduced during the production process
Publisher's Note Springer Nature remains neutral with regard to jurisdictional claims in published maps and institutional affiliations.

The original article can be found online at https://doi.org/10.1007/ s12630-020-01653-0.

V. Ip, MBChB, FRCA · T. J. P. Özelsel, MD, DESA

Department of Anesthesia and Pain Medicine, University of Alberta, Edmonton, AB, Canada

R. V. Sondekoppam, MBBS, MD

Department of Anesthesia, University of Iowa Hospital, Iowa

City, IA, USA

B. C. H. Tsui, MD, MSc, FRCPC ( $\varangle)$

Department of Anesthesiology, Perioperative, and Pain

Medicine, Stanford University School of Medicine, Palo Alto,

CA, USA

e-mail: bantsui@stanford.edu 